\title{
Biomass Productivity of Different Winter Cover Crops and Their Effect on Soil Physical Properties
}

\author{
Willian dos Reis ${ }^{1}$, Monica C. Sustakowski ${ }^{1}$, Edleusa P. Seidel ${ }^{1}$, Maria do C. Lana ${ }^{1}$, Renata F. Barabasz ${ }^{1}$ \\ \& Natália C. dos Santos ${ }^{1}$ \\ ${ }^{1}$ Center of Agrarian Science, State University of Western Paraná, Paraná, Brazil \\ Correspondence: Willian dos Reis, Center of Agrarian Science, State University of Western Paraná, Paraná, \\ 85960-000, Brazil. Tel: 55-45-99842-2750. E-mail: willian haje@hotmail.com
}

Received: August 3, 2020

doi:10.5539/jas.v12n10p338

\author{
Accepted: September 3, 2020 \\ Online Published: September 15, 2020
}

URL: https://doi.org/10.5539/jas.v12n10p338

\begin{abstract}
The cultivation of cover crops is a vegetative practice considered an alternative for sustainable soil management, due to its beneficial action in different aspects of soil properties. Thus, the present work aimed to evaluate the effect of cultivation of different species of cover crops on soil density, porosity and diameter of soil aggregates. The experimental design was in randomized blocks, with four replications. The treatments consisted of four species of winter green manure: black oat, forage turnip, forage pea, and common vetch, a consortium of black oat + forage turnip and area kept fallow (control). The following evaluations were performed: dry matter production of cover crops, macroporosity, microporosity, total porosity, soil density, geometric mean diameter and weighted average diameter. The cultivation with forage turnip and the consortium of black oat + forage turnip presented higher dry matter productivity, decreased soil density, increased soil porosity, improved the distribution in relation to macropores and aggregate stability.
\end{abstract}

Keywords: aggregate stability, crop rotation, organic matter, soil porosity

\section{Introduction}

Soil quality is defined as the efficiency of a soil in maintaining its productive capacity. However, the inadequate use of soil and the use of inappropriate management systems have led to the degradation of its physical and chemical properties (Cunha, Stone, Ferreira, Didonet, \& Moreira, 2012).

The use of inadequate soil and crop management techniques, such as soil tillage methods that intensely mobilize the arable layer, are the main promoters of changes in soil physical properties, causing the degradation of the structure, by fractionation of macroaggregates, and reducing pore continuity. These processes, associated with the intense traffic of agricultural machinery and the downward movement of dispersed clays, promote the approximation of soil particles, resulting in increased density (Kochhenn \& Denardin, 2000).

Oliveira, Lima, and Verburg (2015) report that the use of management strategies, maintenance of cover and the incorporation of organic matter, allow the recovery of the structure and soil conservation for future generations (Rossetti, Andrioli, Centurion, Matias, \& Nóbrega, 2012).

Soil physical destructuring is a component of the soil degradation process, which is usually associated with losses in organic matter content, increased compaction rate, and lack of soil protection from rain impacts (Guimarães, Tormena, Blainski, \& Fidalski, 2013; Lima, Leon, \& Silva, 2013). As a consequence of the physical degradation of the soil structure, there are changes in the physical attributes of the soil that control processes related to the dynamics of water, air, heat and root growth (Shi et al., 2012; Guimarães et al., 2013).

The development of agricultural systems has modified the physical properties of the soil, whose intensity varies according to climatic conditions, relief, management intensity and the very constitution of the soil (Tavares Filho \& Tessier, 2010; Torres, Fabian, \& Pereira, 2011). Several soil management practices should be used to minimize and avoid soil destructuring and losses, and among them, crop rotations and the use of green manure or cover crops (Brady \& Weil, 2013).

The rotation of crops with green manure in the no-tillage system promotes a diversity of the soil microbiota, favoring the stability of soil aggregates and their quality (Moro, Crusciol, Nascente, \& Cantarella, 2013; Araujo, Cunha, Silveira, Souza Neto, \& Oliveira, 2015). Green manure, commonly called protective plants, improving 
plants, or soil cover crops are cultivated for the primary purpose of protecting the soil, attenuating the impact of raindrops and the incidence of sunlight. After its desiccation or rollover its residues are on the soil for a certain time, and with its decomposition there is release of nutrients to the following crops.

According to Rossi, J. Valle, and C. Valle (2002), other benefits of the cultivation of cover crops is the increase in the rate of water infiltration, due to the combined effect of the root system and the area part in promoting a large and continuous input of plant mass to the soil, in order to maintain, or even raise the organic matter content of the soil. Debiasi, Levien, Trein, Conte, and Kamimura (2010), demonstrate that the use of cover crops in the winter period is an excellent alternative for attenuating the effects of soil compaction in areas under no-tillage system.

The use of cover crops promotes the opening of channels in the soil resulting from the growth of its roots, which are fundamental for water availability and nutrient flow, besides that from the decomposition of the roots there is the return of nutrients extracted from the deeper layers of the soil, which promotes better conditions for the root development of the successor crop, enabling access to water and nutrients present in deeper layers, thus avoiding possible losses in production, besides promoting benefits in soil structuring (Santos et al., 2014).

Therefore, the replacement of fallow-held areas by management systems that introduce species and that have no soil mobilization can promote increases in organic matter content, which, according to Calonego (2007), will act in increasing macroporosity and in the formation and stabilization of soil aggregates, through root exploration in the soil profile, which during the growth process promote the approximation of particles and also through the release of organic exudates that act as cementing substances of soil particles.

Thus, it is perceived that the use of soil conservation practices is of great importance, especially in relation to the improvement and maintenance of the physical, chemical and biological properties of the soil and its inferences in crop yield (Argenton, Albuquerque, Bayer, \& Wildner, 2005).

In view of the above, the objective of this work was to evaluate the dry mass production of winter cover plants and their effect on soil physical attributes.

\section{Material and Methods}

\subsection{Location, Climate and Soil of the Experimental Area}

The work was carried out in the municipality of Marechal Cândido Rondon, State of Paraná, Brazil, under the geographical coordinates of latitude $24^{\circ} 31^{\prime} 58.24^{\prime \prime} \mathrm{S}$ and longitude $54^{\circ} 01^{\prime} 11.08^{\prime \prime} \mathrm{W}$ and with an altitude of 390 meters in relation to sea level.

According to the Köppen classification the climate of the region is of the subtropical humid mesothermal Cfa type of dry winter, with well distributed rains throughout the year and hot summers (Caviglione, Kiihl, Caramori, \& Oliveira, 2000). The temperature and precipitation for the months in which the experiment was conducted are presented in Figure 1.

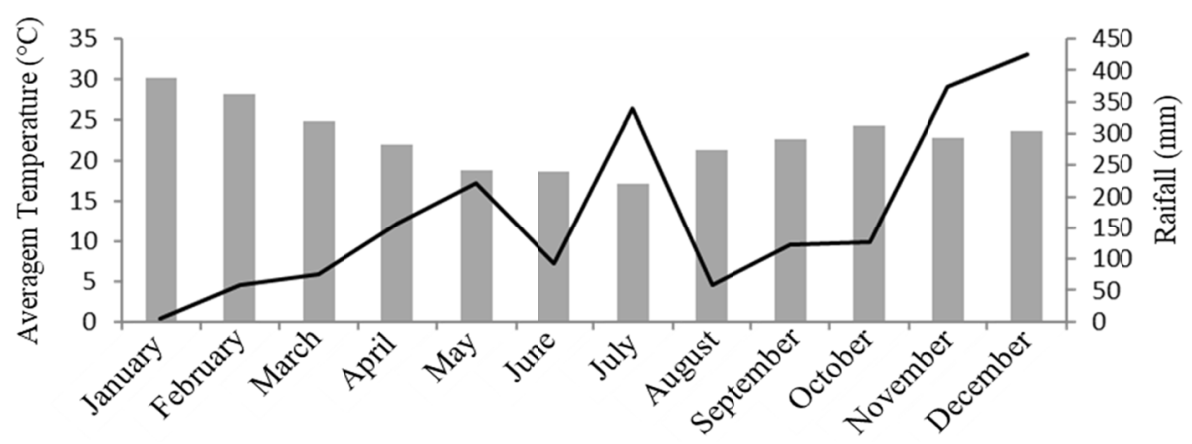

Figure 1. Rainfall (column) and average temperature (line) in 2015 in the municipality of Marechal Cândido Rondon, Paraná, Brazil

The soil of the experimental area was classified as a Dystropical Red Latosol (LVdf) (Ferralsol, by FAO (2015)) (Santos et al., 2013). Soil samples were collected at a depth of 0.0-0.20 m to determine chemical characteristics before the experiment. The soil presented the following chemical characteristics: $\mathrm{pH}\left(\mathrm{CaCl}_{2}\right)=4.40 ; \mathrm{P}=7.52 \mathrm{mg}$ 
$\mathrm{dm}^{-3} ; \mathrm{K}^{+}=0.22 \mathrm{cmol}_{\mathrm{c}} \mathrm{dm}^{-3} ; \mathrm{Ca}^{2+}=2.15 \mathrm{cmol}_{\mathrm{c}} \mathrm{dm}^{-3} ; \mathrm{Mg}^{2+}=0.74 \mathrm{cmol}_{\mathrm{c}} \mathrm{dm}^{-3} ; \mathrm{Al}^{3+}=0.45 \mathrm{cmol}_{\mathrm{c}} \mathrm{dm}^{-3} ; \mathrm{SB}=3.11$ $\mathrm{cmol}_{\mathrm{c}} \mathrm{dm}^{-3} ; \mathrm{CTC}=8.99 \mathrm{cmol}_{\mathrm{c}} \mathrm{dm}^{-3} ; \mathrm{OM}=16.40 \mathrm{~g} \mathrm{dm}^{-3} ;$ and V $(\%)=34.59$.

\subsection{Experimental Design}

The experimental design was in randomized blocks, with four replications. The treatments consisted of four winter cover crops: black oat (Avena strigosa), forage turnip (Raphanus sativus L.), pea-forage (Pisum sativum L. subspecies arvense), common vetch (Vicia sativa L.), in addition to a consortium of black oat + forage turnip and area maintained in fallow (control). Each block was composed of six plots referring to green manure and fallow area, and each plot had dimensions of $4.5 \mathrm{~m}$ wide and $7 \mathrm{~m}$ long; the blocks were spaced with a distance of $2 \mathrm{~m}$, totaling an experimental area of $1288 \mathrm{~m}^{2}$. For data collection, a useful area of $31.5 \mathrm{~m}^{2}$ was determined in each plot.

\subsection{Conducting the Experiment}

For the implementation of the experiment, weed control was performed with the desiccation of the area using non-selective herbicides and systemic action Roundup ${ }^{\circledR}$ (Glyphosate) at the dose of $2 \mathrm{~L} \mathrm{ha}^{-1}$ for a volume of 200 L.ha ${ }^{-1}$ of water.

The sowing of winter cover crops was performed mechanically, in a spacing of $17 \mathrm{~cm}$ between rows for all species, according to the recommended density, using a parcel seeder coupled to a tractor. The following sowing densities were used: black oat $\left(60 \mathrm{~kg} \mathrm{ha}^{-1}\right)$; forage turnip $\left(12 \mathrm{~kg} \mathrm{ha}^{-1}\right)$; common vetch $\left(60 \mathrm{~kg} \mathrm{ha}^{-1}\right)$; forage pea (60 $\left.\mathrm{kg} \mathrm{ha}^{-1}\right)$; forage turnip intercropping $\left(12 \mathrm{~kg} \mathrm{ha}^{-1}\right)+$ black oat $\left(60 \mathrm{~kg} \mathrm{ha}^{-1}\right)$. Planting fertilization was performed with $200 \mathrm{~kg} \mathrm{ha}^{-1}$ of the formulated 10-15-15 $\left(\mathrm{N}^{-} \mathrm{P}_{2} \mathrm{O}_{5}-\mathrm{K}_{2} \mathrm{O}\right)$. No cultural treatment was necessary during the development of the cover plants, and only the monitoring of their development was made.

\subsection{Evaluation and Statistical Analysis of the Data}

At 88 days after sowing, physiological period equivalent to the flowering of the species, the plants were managed using a gasoline brush cutter, with sectioning of the plants at ground level. To determine the dry matter production, a metallic square with a known area of $0.25 \mathrm{~m}^{2}$ was used, which was arranged in the useful area and all the plant material contained inside it was collected and packed in paper bags. Subsequently, they were sent to the dried in forced air oven at $65{ }^{\circ} \mathrm{C}$ until constant weight for subsequent determination of dry mass in a electronic scale.

After the management of cover crops, the physical properties of the soil were evaluated, being: stability of the aggregates, soil density, macroporosity, microporosity and total porosity.

The evaluation of the stability of wet aggregates was performed before the implementation of the experiment and after four months of the implementation of the experiment, when the plants had already been managed. Samples of monoliths were collected with one shovel, at layer of 0.00 to $0.10 \mathrm{~m}$ and 0.10 to $0.20 \mathrm{~m}$ and their determination performed according to the methodology proposed by Madari (2004), in Yooder apparatus (agitator with vertical oscillation). The set of sieves used presented an opening of 2.00, 1.00, 0.50, 0.25 and $0.105 \mathrm{~mm}$ mesh and from the aggregate mass obtained in each sieve it was determined of the weighted average diameter and the geometric mean diameter according to the methodology proposed by Kemper and Rosenau (1986).

For soil density, macroposity, microposity and total porosity, undisturbed soil samples were collected in a volumetric ring at layer from 0.00 to $0.10 \mathrm{~m}$, from 0.10 to $0.20 \mathrm{~m}$ and from 0.20 to $0.30 \mathrm{~m}$. For the determination of pore volume, the samples were saturated by means of gradual elevation of a water depth, until $2 / 3$ of the ring height. After saturation, the samples were weighed and submitted to a tension table with a potential of -0.006 MPa (light suction) equivalent to a water column of $0.60 \mathrm{~m}$ high, thus draining the water contained in the macropores. After draining, the samples were weighed and taken to an oven with forced air circulation at $105{ }^{\circ} \mathrm{C}$ for 48 hours and then weighed. The macropores were estimated by the difference between the water content of the saturated soil and the water content after the application of the defined stress. The volume of micropores was estimated by the difference between the water content afeter the application of the defined stress and oven drying. Soil density was determined according to the methodology proposed by Almeida, Vian., Teixeira, and Donagemma (2017).

The data obtained were tabulated and submitted to analysis of variance considering a significance level of $5 \%$ for the F test. When significant, the means were compared using the Tukey test at 5\% probability, using the Sisvar statistical software (Ferreira, 2014). 


\section{Results and Discussion}

There were significant differences $(\mathrm{p}<0.05)$ in dry matter produtivity of cover crops. The highest dry matter yield was observed with the forage turnip and the consortium of black oat + forage turnip, with an average productivity of these of $4885 \mathrm{~kg} \mathrm{ha}^{-1}$. While the area with the lowest productivity was the one kept fallow with $2189 \mathrm{~kg} \mathrm{ha}^{-1}$ and did not differ from the productivity of vetch and pea forage. Black oat showed an intermediate yield of $3178 \mathrm{~kg} \mathrm{ha}^{-1}$ (Figure 2).

This productivity of dry matter in the fallow area is due to the high incidence of weeds; and even the forage turnip presence that was born by reseeding, since the fallow area was not grassed during the crop cycle.

The productivity of dry matter observed in this experiment was similar to that obtained by Silva et al. (2007), which obtained for single black oats and black oat + forage turnip a yield of 3600 and $4700 \mathrm{~kg} \mathrm{ha}^{-1}$.

The low dry matter production of the common vetch can be attributed to its slow initial growth and to the management time of the cover (Nunes, Souza, \& Mercante, 2011), considering that the dry matter production of this crop differed in only $114 \mathrm{~kg}$ ha- 1 of the fallow area. It is important to highlight that among the species used, common vetch was a crop that had greater sensitivity to climatic conditions, and in this experiment as shown in Figure 1, there was a period of low rainfall during its initial development, which influenced the productive potential of this species.

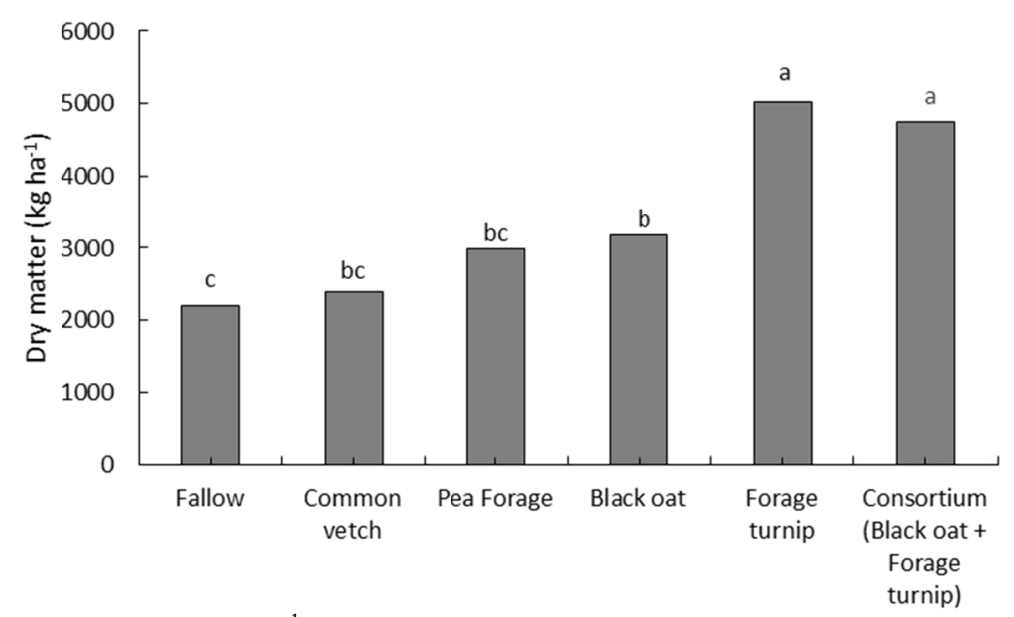

Figure 2. Dry matter yield $\left(\mathrm{kg} \mathrm{ha}^{-1}\right)$ after growing winter cover crops in Marechal Cândido Rondon, Paraná, Brazil

Note. * Equal letters between green manures do not differ statistically by the Tukey test at $5 \%$ significance.

The high yields of dry matter of the aerial part of winter species, in general, show their potential as green fertilization, especially in the intercropping of species with different root systems, when compared to the isolated cultivation of black oat. With this management strategy, an adequate amount of dry mass can be maintained on the soil surface, important for the sustainability of the no-tillage system.

For soil density, macroporosity (Ma), microporosity (Mi) and total porosity (PT), significant differences were found between the winter cover crops at the different layer evaluated (Table 1). At the depth of 0.0-0.10 m the highest soil density was found in the fallow area $\left(1.42 \mathrm{Mg} \mathrm{m}^{-3}\right)$, which differed from the soil density in the area with the intercropping $\left(1.16 \mathrm{Mg} \mathrm{m}^{-3}\right)$; that is, a $22 \%$ reduction in soil density (Table 1$)$. In all layer evaluated, vetch was not able to promote reduction in soil density in relation to fallow area.

For the macroporisity, the consortium area obtained a significant difference in all layer in relation to the fallow area, differing from the data obtained for the microporosity where there was less value for the consortium in all layer, on average $0.3955 \mathrm{~m}^{3} \mathrm{~m}^{-3}$, demonstrating improvements in the distribution of pores in the soil, since the decrease within the microporosity may indicate an increase in the amount of macroposity, which was observed in practically all layer evaluated.

For the total porosity of $0.0-0.10 \mathrm{~m}$, a higher value of the area under cultivation of forage turnip was obtained in relation to the fallow area, this is due to the aggressive root system of the forage turnip, also favoring a better 
distribution between the pore sizes, which can be seen in the composition of microporosity and macroporosity in Table 1.

It is possible to observe that, in general, the intercropping and the cultivation of isolated forage turnips presented macroporosity values close to or even greater than $0.10 \mathrm{~m}^{3} \mathrm{~m}^{-3}$, and values below this can be limiting to the soil that will certainly influence the speed of water infiltration and the adequate supply of oxygen to the roots (Girardello et al., 2011).

According to Marques, Libardi, Teixeira, and Reis (2004), the higher volume of micropores is directly related to the water retention capacity in the soil, however the decrease in microposity observed in turnip and intercropping treatments occurred due to the increase in macropore distribution, causing improvements in water infiltration and soil aeration in depth.

Table 1. Averages for microporosity, macroporosity, total porosity and soil density of winter cover crops at different layer



Note. Lowercase letters different in the column for each depth indicates significant difference by Tukey test at $5 \%$ probability of error level.

In relation to the diameter of the aggregates, statistical differences were observed in the second evaluation (four months after the implantation of the fertilizers) and in the depth of 0.10 to $0.20 \mathrm{~m}$ (Table 2).

It is observed that the consortium of black oat + forage turnip contributed to higher values of weighted average diameter $(1.98 \mathrm{~mm})$ and geometric mean diameter $(1.95 \mathrm{~mm})$ at a depth of 0.10 to $0.20 \mathrm{~m}$ (Table 2).

It is possible to observe that between the first evaluation, before the implementation of the treatments and the second evaluation, after four months, there were increases on the AWD and GMD, in all treatments and soil layer. The lower values found in the first evaluation can be attributed to the intense mechanization process, which in turn promotes the fragmentation of larger aggregates into smaller aggregates.

Similar results were found by Pereira, Olszevski, and Mendes (2013) and according to Calonego and Rosolem (2008), observed that the soil tillage presented a lower percentage of aggregates smaller than $2 \mathrm{~mm}$ in relation to treatments with crop rotation that presented larger aggregates.

In the second evaluation for weighted mean diameter and geometric mean diameter, the greatest results were observed in the black oat + forage turnip consortium at a depth of $0.10-0.20 \mathrm{~m}$. Ribon, J. Centurion, M. 
Centurion, Fernandes, and Hermogenes (2014), found similar results and they affirm that through the use of cover crops there is an increase in the stability of aggregates, due to the higher content of organic matter from plant mass.

To Ribon et al. (2014), the improvements in the stability of aggregates is related to organic matter that acts as an aggregating agent in the soil. Demarchi, Perusi, and Piroli (2011), found the largest aggregates in pastures when compared to the native Cerrado, this is certainly due to greater deposition in depth of roots and surface residues.

The different size classes of the aggregates are influenced by organic matter, the amount of which will allow greater or lesser aggregation, resulting in less or greater soil loss (Castro Filho \& Logan, 1991). Perin, Guerra, Teixeira, Pereira, and Fontana (2002) observed that the soil under cover of perennial herbaceous legumes presents higher aggregation rates than uncovered areas.

Table 2. Mean values of weighted average diameter (AWD) and geometric mean diameter (GMD) of aggregates, at different layer, after cultivation of winter cover crops

\begin{tabular}{llllll}
\hline \multirow{2}{*}{ Cover crops } & \multicolumn{2}{c}{ 1st Evaluation } & & \multicolumn{2}{c}{ 2nd Evaluation } \\
\cline { 2 - 3 } \cline { 5 - 6 } & AWD & GMD & & AWD & GMD \\
\hline Layer 0.00-0.10 $m$ & & & & \\
Forage Turnip & $1.33^{\mathrm{ns}}$ & $0.98^{\mathrm{ns}}$ & & $1.57^{\mathrm{ns}}$ & $1.32^{\mathrm{ns}}$ \\
Black Oat & 1.37 & 0.95 & & 1.50 & 1.30 \\
Fallow & 1.29 & 1.01 & & 1.11 & 0.79 \\
Consortium (Oats+Turnip) & 1.17 & 0.84 & & 1.34 & 1.07 \\
Pea Forage & 1.33 & 0.93 & & 1.47 & 1.07 \\
Common Vetch & 1.11 & 0.79 & & 1.12 & 1.16 \\
Layer 0.10-0.20 $m$ & & & & \\
Forage Turnip & $1.20^{\mathrm{ns}}$ & $0.86^{\mathrm{ns}}$ & & $1.75 \mathrm{ab}$ & $1.39 \mathrm{ab}$ \\
Black Oat & 1.17 & 1.25 & & $1.47 \mathrm{ab}$ & $1.26 \mathrm{ab}$ \\
Fallow & 1.37 & 1.03 & & $1.09 \mathrm{~b}$ & $0.80 \mathrm{~b}$ \\
Consortium (Oats+Turnip) & 1.47 & 1.16 & & $1.98 \mathrm{a}$ & $1.95 \mathrm{a}$ \\
Pea Forage & 0.96 & 0.61 & & $1.78 \mathrm{ab}$ & $1.59 \mathrm{ab}$ \\
Common Vetch & 1.26 & 0.92 & & $1.44 \mathrm{ab}$ & $1.13 \mathrm{ab}$ \\
\hline
\end{tabular}

Note. ${ }^{\text {ns }}$ not significant at a $5 \%$ probability. Lowercase letters in the column indicate a significant difference by the Tukey test at the $5 \%$ probability level.

The stable aggregates of larger size indicate a good soil structure, because soils with a large amount of aggregates have in their profile a larger porous space, thus providing a better development of roots, fauna and air and water circulation (R. Ferreira, Tavares Filho, \& V. Ferreira, 2010).

According to Salton et al. (2008), these conditions are achieved with management systems such as permanent pasture, crop rotation or use of cover crops and the use of no-tillage system, that is, management practices that favor the formation of larger aggregates.

Considering that the higher the percentage of aggregates retained in the sieves with larger meshes, the higher the WAD and that the MGD represents an estimate of the class of aggregates of higher occurrence (Hickmann, Costa, Schaefer, \& Fernandes, 2011), consequently, these also did not differ statistically.

In view of these results, the species consortium strategy (black oats + turnip) is important to provide more adequate amounts of residues on the soil surface when compared to isolated systems and fallow land, and is also essential for improving soil sustainability and cycling of nutrients. Due to the characteristics of the forage turnip in decompressing the soil, providing better soil coverage and the ability to extract nutrients from the deeper layers, they may have contributed to the increase in the development of black oats and high mass production in the intercropping area.

\section{Conclusions}

The treatments using single forage turnip and the consortium of black oat + forage turnip turned out to be the highest amount of dry matter, decreased soil density, increased soil porosity, improved the distribution in relation to macropores and aggregate stability. 


\section{Acknowledgements}

The authors would like to thank the State University of Western Paraná for their support in the development of the research.

\section{References}

Almeida B, G. de, Viana, J. H. M., Teixeira, W. G., \& Donagemma, G. K. (2017). Densidade do solo. In P. C. Teixeira, G. K. Donagemma, A. Fontana, \& W. G. Teixeira (Eds.), Manual de métodos de análise de solo (pp. 65-75). Brasília: Embrapa.

Araujo, L. S., Cunha, P. C. R. da, Silveira, P. M. da, Souza Neto, M. de, \& Oliveira, F. C. de. (2015). Potencial de cobertura do solo e supressão de tiririca (Cyperus rotundus) por resíduos culturais de plantas de cobertura. Revista Ceres, 62(5), 483-488. https://doi.org/10.1590/0034-737X201562050009

Argenton, J., Albuquerque, J. A., Bayer, C., \& Wildner, L. do P. (2005). Comportamento de atributos relacionados com a forma da estrutura de Latossolo vermelho sob sistemas de preparo e plantas de cobertura. Revista Brasileira de Ciência do Solo, 29(3), 425-435. https://doi.org/10.1590/S0100-06832005 000300013

Brady, N. C., \& Weil, R. R. (2013). Elementos da natureza e propriedades dos solos (3rd ed., p. 704). Porto Alegre: Bookman.

Calonego, J. C. (2007). Uso de plantas de cobertura na recuperação de solo compactado (Tese de Doutorado. Universidade Estadual Paulista “Julio de Mesquita Filho”, Botucatu, São Paulo, Brazil).

Calonego, J. C., \& Rosolem, C. A. (2008). Estabilidade de agregados do solo após manejo com rotações de culturas e escarificação. Revista Brasileira de Ciência do Solo, 32(4), 1399-1407. https://doi.org/10.1590/ S0100-06832008000400004

Castro Filho, C., \& Logan, T. J. (1991). Liming effects on the stability and erodibility of some Brazilian Oxisols. Soil Science Society of America Journal, 55, 1407-1413. https://doi.org/10.2136/sssaj1991.036159950055 $00050034 \mathrm{x}$

Caviglione, J. H., Kiihl, L. R. B., Caramori, P. H., \& Oliveira, D. (2000). Cartas climáticas do Paraná. Londrina: Instituto Agronômico do Paraná (IAPAR).

Cunha, E. Q., Stone, L. F., Ferreira, E. P. B., Didonet, A. D. E., \& Moreira, J. A. A. (2012). Atributos físicos, químicos e bilógicos de solo sob produção orgânica impactados por sistemas de cultivo. Revista Brasileira de Engenharia Agrícola e Ambiental, 16(1), 56-63. https://doi.org/10.1590/S1415-43662012000100008

Debiasi, H., Levien, R., Trein, C. R., Conte, O., \& Kamimura K. M. (2010). Produtividade de soja e milho após coberturas de inverno e descompactação mecânica do solo. Pesquisa Agropecuária Brasileira, 45(6), 603-612. https://doi.org/10.1590/S0100-204X2010000600010

Demarchi, J. C., Perusi, M. C., \& Piroli, E. L. (2011). Análise da estabilidade de agregados de solos da microbacia do Ribeirão São Domingos, Santa Cruz do Rio Pardo-SP, sob diferentes tipos de uso e ocupação. Revista Brasileira de Tecnologia Aplicada nas Ciências Agrárias, 4(2), 7-29. https://doi.org/10.5777/ PAeT.V4.N2.01

Ferreira, D. F. (2014). Sisvar: A guide for its bootstrap procedures in multiple comparisons. Ciência e Agrotecnologia, 38(2), 109-112. https://doi.org/10.1590/S1413-70542014000200001

Ferreira, R. R. M., Tavares Filho, J., \& Ferreira, V. M. (2010). Efeitos de sistemas de manejo de pastagens nas propriedades físicas do solo. Semina: Ciências Agrárias, 31(4), 913-932. https://doi.org/10.5433/1679-0359. $2010 v 3 \ln 4$ p913

Girardello, V. C., Amado, T. J. C., Nicoloso, R. S., Hörbe, T. A. N., Ferreira, A. O., Tabaldi, F. M., \& Lanzanova, M. E. (2011). Alterações nos atributos físicos de um Latossolo vermelho sob plantio direto induzidas por diferentes tipos de escarificadores e o rendimento da soja. Revista Brasileira de Ciência do Solo, 35(6), 2115-2126. https://doi.org/10.1590/S0100-06832011000600026

Guimarães, R. M. L., Tormena, C. A., Blainski, E., \& Fidalski, J. (2013). Intervalo hídrico ótimo para avaliação da degradação física do solo. Revista Brasileira de Ciência do Solo, 37(6), 1512-1521. https://doi.org/ 10.1590/S0100-06832013000600008

Hickmann, C., Costa, L. M. da, Schaefer, C. E. G. R., \& Fernandes, R. B. A. (2011). Morfologia e estabilidade de agregados superficiais de um argissolo vermelho-amarelo sob diferentes manejos de longa duração e 
mata atlântica secundária. Revista Brasileira de Ciência do Solo, 35(6), 2191-2198. https://doi.org/10.1590/ S0100-06832011000600034

Kemper, W. D., \& Rosenau, R. C. (1986). Aggregate stability and size distribution. In A. Klute (Ed.), Methods of soil analysis. Parte 1: Physical and mineralogical methods (pp. 425-443). Madison: American Society of Agronomy. https://doi.org/10.2136/sssabookser5.1.2ed.c17

Kochhann, R. A., \& Denardin, J. E. (2000). Implantação e Manejo do Sistema Plantio Direto (Embrapa Trigo, Documentos 20, p. 36). Passo Fundo: Embrapa Trigo.

Lima, R. P., Leon, M. J., \& Silva, A. R. (2013). Compactação do solo de diferentes classes texturais em áreas de produção de cana-de-açúcar. Revista Ceres, 60(1), 16-20. https://doi.org/10.1590/S0034-737X20130 00100003

Madari, M. E. (2004). Fracionamento de agregados: Procedimento para uma estimativa compartimentada do sequestro de carbono no solo (Comunicado Técnico 22). Empresa Brasileira de Pesquisa Agropecuária (EMBRAPA), Rio de Janeiro.

Marques, J. D. O., Libardi, P. L., Teixeira, W. G., \& Reis, A. M. (2004). Estudo de parâmetros físicos, químicos e hídricos de um Latossolo Amarelo, na região Amazônica. Acta Amazônica, 34(2), 145-154. https://doi.org/ $10.1590 / \mathrm{S} 0044-59672004000200002$

Moro, E., Crusciol, C. A. C., Nascente, A. S., \& Cantarella, H. (2013). Teor de nitrogênio inorgânico no solo em função de plantas de cobertura, fontes de nitrogênio e inibidor de nitrificação. Pesquisa Agropecuária Tropical, 43(4), 424-435. https://doi.org/10.1590/S1983-40632013000400003

Nunes, A. S., Souza, L. C. F., \& Mercante, F. M. (2011). Adubos verdes e adubação mineral nitrogenada em cobertura na cultura do trigo em plantio direto. Bragantia, 70(2), 432-438. https://doi.org/10.1590/S000687052011000200026

Oliveira, D. M. S., Lima, R. P., \& Verburg, E. E. J. (2015). Qualidade física do solo sob diferentes sistemas de manejo e aplicação de dejeto liquido suíno. Revista Brasileira de Engenharia Agrícola e Ambiental, 19(3), 280-285. https://doi.org/10.1590/1807-1929/agriambi.v19n3p280-285

Pereira, J. S., Olszevski, N., \& Mendes, A. M. S. (2013). Avaliação da qualidade estrutural de solos sob uso agrícola no município de Sobradinho-BA. Congresso Brasileiro de Ciência do Solo, Florianópolis, SC. Retrieved from https://ainfo.cnptia.embrapa.br/digital/bitstream/item/90049/1/Alessandra-1.pdf

Perin, A., Guerra, J. G. M., Teixeira, M. G., Pereira, M. G., \& Fontana, A. (2002). Efeito da cobertura viva com leguminosas herbáceas perenes na agregação de um Argissolo. Revista Brasileira de Ciência do Solo, 26(3), 713-720. https://doi.org/10.1590/S0100-06832002000300016

Ribon, A. A., Centurion, J. F., Centurion, M. A. P. C., Fernandes, K. L., \& Hermogenes, V. T. L. (2014). Alterações na estabilidade de agregados de Latossolo e Argissolo em função do manejo, na entrelinha da seringueira (Hevea brasiliensis). Revista Árvore, 38(6), 1065-1071. https://doi.org/10.1590/S0100-6762201 4000600011

Rossetti, K. V., Andrioli, I., Centurion, J. F., Matias, S. S. R., \& Nóbrega, J. C. A. (2012). Atributos físicos do solo em diferentes condições de cobertura vegetal em área de plantio direto. Revista Brasileira de Ciências Agrárias, 7(3), 427-433. https://doi.org/10.5039/agraria.v7i3a1681

Rossi, F., Valle, J. C. V., \& Valle, C. R. P. (2002). Como tornar sua fazenda orgânica (p. 364). Viçosa-MG: CPT.

Salton, J. C., Mielniczuk, J., Bayer, C., Boeni, M., Conceição, P. C., Fabrício, A. C., ... Broch, D. L. (2008). Agregação e estabilidade de agregados do solo em sistemas agropecuários em Mato Grosso Do Sul. Revista Brasileira de Ciência do Solo, 32(1), 11-21. https://doi.org/10.1590/S0100-06832008000100002

Santos, F. S., Zanão Junior, L. A., Secco, D., Dias, P. P., Tomassoni, F., \& Pereira, N. (2014). A utilização de plantas de cobertura na recuperação de solos compactados. Acta Iguazu, 3(3), 82-91.

Santos, H. G. dos, Jacomine, P. K. T., Anjos, L. H. C. dos, Oliveira, V. A. de, Lumbreras, J. F., Coelho, M. R., ... Oliveira, J. B. de. (2013). Sistema Brasileiro de Classificação de Solos (3rd ed., p. 353). Brasília: Empresa Brasileira de Pesquisa Agropecuária (EMBRAPA).

Shi, X. H., Yang, X. M., Drury, C. F., Reynolds, W. D., Mclaughlin, N. B., \& Zhang, X. P. (2012). Impact of ridge tillage on soil organic carbon and selected physical properties of a clay loam in southwestern Ontario. Soil \& Tillage Research, 120,1-7. https://doi.org/10.1016/j.still.2012.01.003 
Silva, A. A. da, Silva, P. R. F. da, Suhre, E., Argenta, G., Strieder, M. L., \& Rambo, L. (2007). Sistemas de coberturas de solo no inverno e seus efeitos sobre o rendimento de grãos do milho em sucessão. Ciência Rural, 37(4), 928-935. https://doi.org/10.1590/S0103-84782007000400002

Tavares Filho, J., \& Tessier, D. (2010). Effects of different management systems on porosity of oxisols in Parana, Brazil. Revista Brasileira de Ciência do Solo, 34(3), 899-906. https://doi.org/10.1590/S0100-06832010 000300031

Torres, J. L. R., Fabian, M. G., \& Pereira, M. G. (2011). Alterações dos atributos físicos de um Latossolo Vermelho submetido a diferentes sistemas de manejo. Ciência \& Agrotecnologia, 35(3), 437-445. https://doi.org/10.1590/S1413-70542011000300001

\section{Copyrights}

Copyright for this article is retained by the author(s), with first publication rights granted to the journal.

This is an open-access article distributed under the terms and conditions of the Creative Commons Attribution license (http://creativecommons.org/licenses/by/4.0/). 